\title{
Dapagliflozin restores insulin and growth hormone secretion in obese mice
}

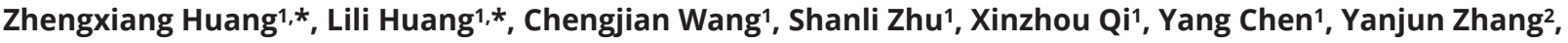 \\ Michael A Cowley 3 , Johannes D Veldhuis ${ }^{4}$ and Chen Chen ${ }^{1}$ \\ 'School of Biomedical Sciences, University of Queensland, St Lucia, Brisbane, Australia \\ 2School of Information Technology and Electrical Engineering, University of Queensland, St Lucia, Brisbane, Australia \\ ${ }^{3}$ Department of Physiology, Monash University, Melbourne, Australia \\ ${ }^{4}$ Department of Medicine, Endocrine Research Unit, Mayo School of Graduate Medical Education, Clinical Translational Science Center, Mayo Clinic, \\ Rochester, Minnesota, USA
}

Correspondence should be addressed to C Chen: chen.chen@uq.edu.au

*(Z Huang and L Huang contributed equally to this work)

\begin{abstract}
The well-documented hormonal disturbance in a general obese population is characterised by an increase in insulin secretion and a decrease in growth hormone $(\mathrm{GH})$ secretion. Such hormonal disturbance promotes an increase in fat mass, which deteriorates obesity and accelerates the development of insulin resistance and type 2 diabetes. While the pathological consequence is alarming, the pharmaceutical approach attempting to correct such hormonal disturbance remains limited. By applying an emerging anti-diabetic drug, the sodium-glucose cotransporter 2 inhibitor, dapagliflozin ( $1 \mathrm{mg} / \mathrm{kg} /$ day for 10 weeks), to a hyperphagic obese mouse model, we observed a significant improvement in insulin and $\mathrm{GH}$ secretion as early as 4 weeks after the initiation of the treatment. Restoration of pathological disturbance of insulin and GH secretion reduced fat accumulation and preserved lean body mass in the obese animal model. Such phenotypic improvement followed with concurrent improvements in glucose and lipid metabolism, insulin sensitivity, as well as the expression of metabolic genes that were regulated by insulin and $\mathrm{GH}$. In conclusion, 10 weeks of treatment with dapagliflozin effectively reduces hyperinsulinemia and restores pulsatile $\mathrm{GH}$ secretion in the hyperphagic obese mice with considerable improvement in lipid and glucose metabolism. Promising outcomes from this study may provide insights into drug intervention to correct hormonal disturbance in obesity to delay the diabetes progression.
\end{abstract}

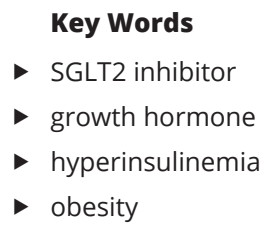

Journal of Endocrinology (2020) 245, 1-12

\section{Introduction}

Hormonal disturbance, in either secretion amount or function, often occurs in parallel with impairment of glucose/lipid/protein metabolism in obesity. Two pivotal hormones, insulin and growth hormone (GH), which synergistically promote protein anabolism whereas exhibit antagonistic effect on lipid and glucose metabolism, play pivotal roles in the development of obesity (Berryman et al. 2013, Templeman et al. 2017). Insulin is secreted from pancreatic beta cells to promote glucose uptake and utilisation as well as lipogenesis (Templeman et al. 2017). 
Excessive insulin secretion (hyperinsulinemia), as often seen in overeating and obesity, leads to desensitisation of insulin receptor and its downstream signalling (Shanik et al. 2008), adipose tissue inflammation (Pedersen et al. 2015), ectopic lipid accumulation in liver and muscle (Morita et al. 2017), and the development of insulin resistance (Samuel \& Shulman 2016). Opposite to insulin, GH exhibits a catabolic effect on lipid metabolism by favouring lipolysis and lipid oxidation (Chia 2014). Secreted from somatotrophs within the anterior pituitary gland, GH displays a pulsatile secretion pattern, with low plasma concentration at baseline and large peaks in rhythmic intervals in all mammalians (Tannenbaum et al. 1976, Winer et al. 1990). This specific secretion pattern is crucial for its effect on lipid metabolism as only pulsatile GH augments the rate of lipolysis in obese humans (Surya et al. 2009). Dynamic analysis revealed a reduction of both GH secretion rate and burst frequency in obese individuals in proportion to the severity of obesity (Veldhuis et al. 1991). Such impairment of GH secretion further impairs fat utilisation.

Therefore, the hormonal disturbance (high insulin and low GH) in obese individuals concurrently drives fuel metabolism towards fat accumulation, which aggravates morbid obesity and may further accelerate insulin resistance and the development of type 2 diabetes (T2D). Restoration of physiological levels of insulin and GH in obesity is of particular importance to maintain healthy body composition and insulin sensitivity, as well as lipid and glucose metabolism.

Sodium-glucose cotransporter 2 inhibitor (SGLT2i) is a new class of drug for overt T2D patients in the clinic, which lowers blood glucose levels by promoting urinary glucose excretion. However, SGLT2i has still not been used for obese patients without T2D in the clinic. Part of the reason is that the general prerequisite for prescription of SGLT2i is hyperglycaemia, whereas the blood glucose level is only slightly elevated in obese individuals due to the compensation of insulin hypersecretion. However, hyperinsulinaemia in obesity leads to on-going hormonal and metabolic disturbances (Miller \& Chapman 2001). Although SGLT2i has been well documented in the improvement of insulin sensitivity in overt T2D patients (Merovci et al. 2016) and obese animals (Nakano et al. 2015, Benetti et al. 2016, Obata et al. 2016, Ji et al. 2017, $\mathrm{Xu}$ et al. 2017), its effect on obesity-related hormonal disturbances, in particular, on pulsatile GH secretion remains undefined. Addressing such a knowledge gap is essential to elucidate some of the untangled observations in previous studies. For example, preserved lean mass following SGLT2i treatment (Obata et al. 2016, Morino et al. 2018) cannot be explained by a reduction of insulin levels but may be rationalised by the protein-preserving effect of GH. Furthermore, a close evaluation of insulin and GH in obesity may further provide mechanistic insights into potential anti-obesity targets in the modulation of metabolism and body composition. Therefore, the main aim of this study is to determine the effects of dapagliflozin, one type of SGLT2i, on two dominant metabolic-regulating hormones (insulin and $\mathrm{GH}$ ) with the corresponding glucose/lipid/protein metabolism in hyperphagic obese melanocortin 4 receptor-knockout (MC4RKO) mice.

\section{Materials and methods}

\section{Animal}

Both MC4RKO and WT mice on C57BL6/J background were obtained from heterozygous breeding pairs and genotyped using established MC4R primer pairs (Tan et al. 2016). Mice were housed under a 12-h light/12-h dark cycle in $22 \pm 2^{\circ} \mathrm{C}$ and $35 \pm 4 \%$ humidity environment at the animal facility of the Institute for Bioengineering and Nanotechnology, the University of Queensland. Mice had free access to chow diet (Specialty Feeds, Glen Forrest, WA, Australia) and water. All experiments and procedures were approved by the Animal Ethics Committee of the University of Queensland.

\section{Experiment design}

To study the chronic effect, 10-week-old MC4RKO mice (both genders) were treated with dapagliflozin (AstraZeneca, Göteborg, Sweden) dissolved in drinking water $(1 \mathrm{mg} / \mathrm{kg} /$ day) for 10 weeks. Age-matched WT and MC4RKO mice with normal drinking water were used as controls. Body weight was measured weekly. Serial blood collection for GH measurement, glucose tolerance test and insulin tolerance test and indirect calorimeter recording were performed at 4, 6, 8 weeks following the initiation of the treatment, respectively. Twenty-four-hour urine samples were individually collected via a metabolic cage. At the end of the treatment, mice were killed following an intraperitoneal injection of sodium pentobarbital (32.5 $\mathrm{mg} / \mathrm{mL}$ ) under fed state. Terminal blood was collected by cardiac puncture and plasma was separated by centrifugation. Tissues were either snap-frozen for gene expression measurement or fixed in $4 \%$ paraformaldehyde 
for immunohistochemistry staining. To study insulin sensitivity, mice receiving 2 -week treatment were fasted for $6 \mathrm{~h}$ and intraperitoneally injected with insulin $(2 \mathrm{U} / \mathrm{kg}$, Insulin solution human, Sigma). Five minutes later, mice were killed, and tissues were collected for insulinstimulated Akt phosphorylation measurement.

\section{Indirect calorimetric assays}

Mice were individually housed in the recording chambers of TSE PhenoMaster (TSE Systems, Germany) with free access to food and water for 3 days. Food intake, water intake and locomotor activity were measured in the whole recording period; respiratory exchange ratio (RER) and oxygen consumption were measured hourly. Body fat mass and lean mass were determined by a NMR device (Bruker, USA).

\section{Glucose tolerance test (GTT) and insulin tolerance test (ITT)}

Mice were fasted for $14 \mathrm{~h}$ and $4 \mathrm{~h}$ before GTT and ITT, respectively. During the experiments, blood glucose levels were measured before (time point 0 ) oral gavage of glucose ( $2 \mathrm{~g} / \mathrm{kg}$ ) for GTT or intraperitoneal injection of human insulin (0.3 U/kg, Insulin solution human, Sigma) for ITT. The blood glucose levels were measured by a Glucose Ketone metre (Nova Stat Strip Xpress Glucose Hospital Meter, Nova Biomedical, UK) at specific time points after oral gavage or injection.

\section{Serial blood collection for GH measurement}

Blood samples were collected for pulsatile GH secretion profile measurement according to the established method (Steyn et al. 2011). Briefly, all mice were trained for 4 weeks before the experiment. The procedure began at 7:30 $\mathrm{h}$ and ended at 13:30 h. During the procedure, $2 \mu \mathrm{L}$ of whole blood was collected from the tail tip of each mouse in a 10 -min interval. For each sample, $2 \mu \mathrm{L}$ of whole blood was added into $58 \mu \mathrm{L} 0.01 \mathrm{M}$ PBS supplemented with $0.05 \%$ Tween 20. Samples were mixed by vortex, snap-frozen by dry ice and stored at $-80^{\circ} \mathrm{C}$ for measurement of $\mathrm{GH}$ by an in-house GH ELISA (Steyn et al. 2011). Due to the influence of the oestrous cycle on the female mice, GH measurement was performed only in male mice.

\section{Hormones and metabolites measurement}

Glucagon and resistin levels in the terminal plasma were measured by the Mouse Metabolic Hormone Magnetic
Bead Panel (Millipore). Plasma insulin level was measured by Rat/Mouse Insulin ELISA Kit (Millipore). Plasma FFA and ketone body levels were measured by NEFA C kit (Wako) and Glucose Ketone Meter, respectively. The triglyceride content in liver and muscle was measured as described previously (Mosa et al. 2017b). The glucose concentration of the urine sample was determined by Glucose Colorimetric Assay Kit (Cayman Chemical). The homeostasis model assessment of insulin resistance (HOMA-IR) was calculated by the equation: HOMA-IR=fasting blood glucose $(\mathrm{mmol} / \mathrm{L}) \times$ fasting plasma insulin $(\mathrm{mU} / \mathrm{L}) / 22.5$.

\section{Pancreas immunohistochemistry}

According to the established methods (Mosa et al. 2017a), sections of paraffin-embedded fixed pancreas ( $7 \mu \mathrm{m})$ were incubated with a mixture of primary antibodies, including mouse anti-insulin (Merck) and rabbit anti-glucagon (Thermo Fisher Scientific) overnight, and then incubated with Alexa Fluor® 488-conjugated and 555-conjugated secondary antibodies (Life Technology). Cell nucleus was stained by Hoechst 33342 (Thermo Fisher). Stained slides were scanned by Nikon Upright Stereology and Slide Scanning Microscope (Nikon), and morphometric measurement was performed using Imaris Image Analysis Software. The mass of alpha or beta cells was calculated by multiplying the percentage of glucagon or insulin-positive area in each section and the weight of the pancreas. In one animal, three non-consecutive pancreas sections and 20-40 islets were measured. All parameters of the microscope and settings were kept constant throughout the whole experiment.

\section{Gene expression measurement}

The total RNA from the liver, muscle, inguinal and epididymal adipose tissues was extracted and purified by PureLink RNA Mini Kit (Thermo Fisher Scientific). $1 \mu \mathrm{g}$ RNA was synthesised into cDNA by iScript ${ }^{\mathrm{TM}} \mathrm{RT}$ Supermix for RT-qPCR (Bio-Rad). For quantitative PCR (qPCR), cDNA was amplified using SsoAdvanced ${ }^{\mathrm{TM}}$ Universal SYBR® Green Supermix (Bio-Rad) and quantified by QuantStudio 6 Flex Real-Time PCR System (Thermo Fisher Scientific). Primer pairs were shown in Supplementary data (Supplementary Table 1, see section on supplementary materials given at the end of this article). The fold change of target gene expression compared to the housekeeping gene (beta-actin) was achieved by the $2^{-\Delta \Delta \mathrm{CT}}$ method. 


\section{Western blot}

Mouse livers were homogenised in buffer containing Protease Inhibitor Cocktail (5892953001, Roche) and phosphatase inhibitor $\left(1 \mathrm{mM} \mathrm{Na}_{3} \mathrm{VO}_{4}, 30 \mathrm{mM} \mathrm{NaF}, 10 \mathrm{mM}\right.$ $\mathrm{Na}_{4} \mathrm{P}_{2} \mathrm{O}_{7}$ ), heat-denatured, separated in $8 \%$ SDS-PAGE, and incubated with the following primary antibodies: anti-pSTAT5 (Tyr694, \#9351, Cell Signalling Technology), anti-STAT5 (\#94205, Cell Signalling Technology), anti-pAkt (Ser473, \#4060, Cell Signalling Technology), anti-Akt (\#4685, Cell Signalling Technology), and anti-alpha-tubulin (ab4074, Abcam). Immunoblots were detected by Odyssey LI-COR CLx Imaging System and quantified using NIH ImageJ software.

\section{Statistics}

Statistical analysis was performed using GraphPad Prism 7 software (excluding deconvolution analysis and analysis of covariance (ANCOVA) for energy expenditure). All results were presented as the mean \pm s.e.m. One-way ANOVA and Student's t-test were used for comparisons among groups. A $P$ value less than 0.05 was considered significant. The quantitative parameters of $\mathrm{GH}$ secretion and clearance associated with observed GH concentration profiles were determined by deconvolution analysis following established parameters (Steyn et al. 2011). Energy expenditure was analysed by ANCOVA following an established method (Speakman et al. 2013) in the MC4RKO mice with or without drug intervention. We excluded wild-type mice in ANCOVA analysis as the genotypic effect was not the observation target. Exclusion criteria also applied to wild-type mice due to the significant body weight and lean mass difference compared to MC4RKO mice as detailed in discussion.

\section{Results}

\section{Dapagliflozin promotes urinary glucose excretion and improves glucose tolerance in MC4RKO mice}

Reminiscent of glucose homeostasis in human obesity, MC4RKO mice had slightly increased fasting ( $4.59 \pm 0.24 \mathrm{vs}$ $3.89 \pm 0.15 \mathrm{mmol} / \mathrm{L})$ and random blood glucose $(8.00 \pm 0.64$ vs $6.72 \pm 0.21 \mathrm{mmol} / \mathrm{L}$ ) (Fig. $1 \mathrm{~A}$ ), as well as slightly impaired glucose tolerance (Fig. 1C and D), compared to WT mice. Dapagliflozin treatment significantly increased daily urinary glucose excretion (Fig. 1B) and water intake
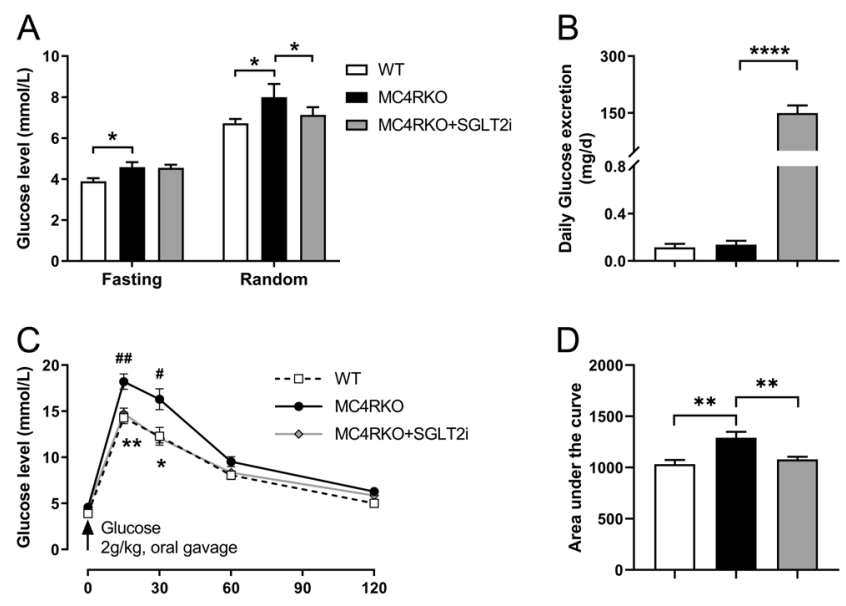

Figure 1

Dapagliflozin promotes urinary glucose excretion and improves glucose tolerance in MC4RKO mice (A), blood glucose level in fasting and random conditions. (B) Daily urinary glucose excretion. (C and D) Glucose tolerance test (GTT) and the area under the curve. Data were presented as means \pm S.E.M., $n=6-8$ each group for daily glucose excretion, $n=12-15$ for blood glucose and GTT. \#P<0.05, \#\#P<0.01 vs WT group; $* P<0.05$, $\star * P<0.01, * * * \star P<0.0001$ vs MC4RKO group.

(Supplementary Fig. 1A), normalised random blood glucose level (Fig. 1A) and improved glucose tolerance (Fig. 1C and D) in MC4RKO mice.

\section{Dapagliflozin corrects the disturbed insulin and $\mathbf{G H}$ levels in MC4RKO mice}

Generally, fasting insulin reflects basal insulin secretion, while fed insulin reflects beta cell function. Therefore, we measured plasma insulin level in both fasting and fed conditions. Pulsatile GH secretion changes significantly upon physiological challenges such as fasting (Ho et al. 1988, Steyn et al. 2012). To better clarify the effect of SGLT2i without physiological disturbance, we measured the GH secretion profile under fed conditions. MC4RKO mice had a 4-fold increase in fasting and a 20-fold increase in fed insulin levels than those in WT mice. Dapagliflozin treatment reduced approximately 70\% of both fasting and fed insulin levels in MC4RKO mice (Fig. 2A and B). The pulsatile and basal GH secretion was suppressed in MC4RKO mice (Fig. 2C, D, E, F and G), reflecting an impairment of $\mathrm{GH}$ secretion similar to the diet-induced obese mice that we previously reported (Huang et al. 2012). Following 4 weeks of dapagliflozin treatment, the amount of pulsatile $\mathrm{GH}$ secretion (Fig. 2E and F) in MC4RKO mice was increased by around three-fold of untreated levels with an increasing trend in basal GH secretion (Fig. 2G). The number of secretory https://joe.bioscientifica.com https://doi.org/10.1530/JOE-19-0385 (c) 2020 Society for Endocrinology Published by Bioscientifica Ltd. Printed in Great Britain 

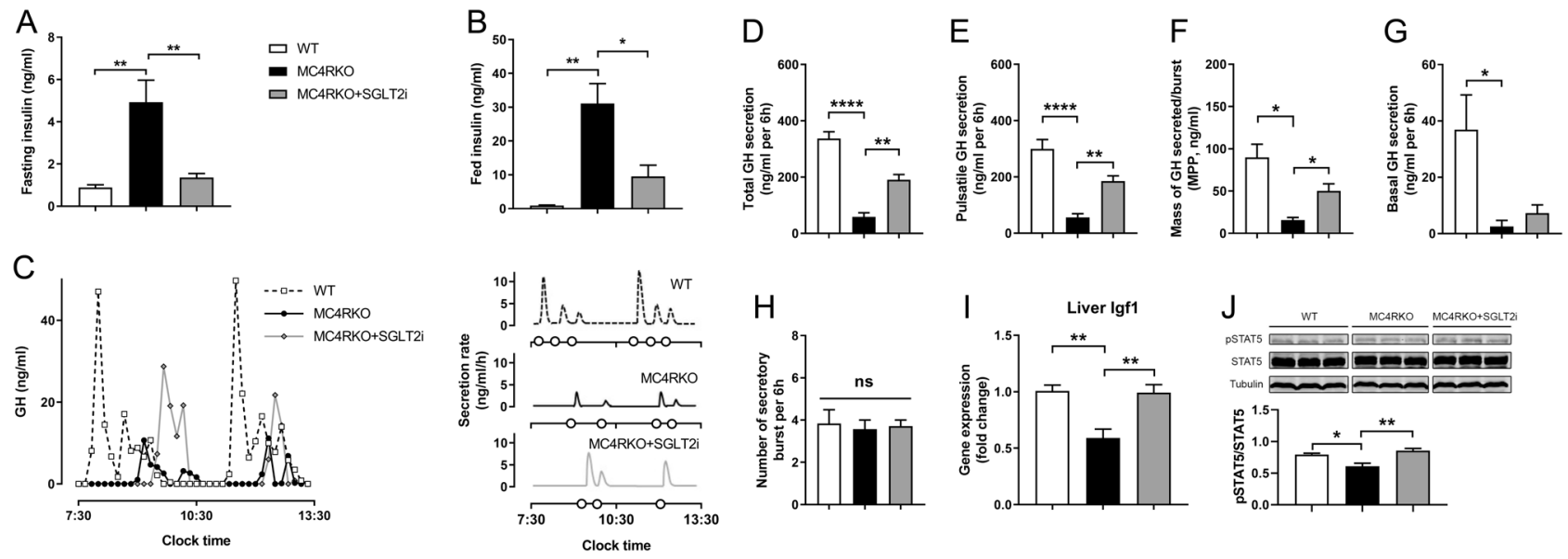

Figure 2

Dapagliflozin reduces hyperinsulinemia and restores pulsatile GH secretion in MC4RKO mice (A), fasting insulin level. (B) Fed insulin level. (C) Representative examples of GH level (left) and the onset of GH secretion pulse (right) in each group during 6-h measurement period. (D, E, F, G and H) Deconvolution analysis revealed the changes of total GH secretion (D), pulsatile $\mathrm{GH}$ secretion (E), mass of $\mathrm{GH}$ secretion per burst (F), basal GH secretion $(\mathrm{G})$, and the number of secretory burst per $6 \mathrm{~h}(\mathrm{H})$. (I) Gene expression levels of Igf1 in liver. (J) STAT5 phosphorylation in liver determined by Western blot. Tubulin served as a loading control. Data were presented as means \pm S.E.M., $n=6-8$ each group. $* P<0.05, * \star P<0.01, * \star * P<0.001, * \star \star \star x<0.0001 ;$ ns, non-significance.

bursts per $6 \mathrm{~h}$ among WT, MC4RKO and dapagliflozin treatment group remained unchanged (Fig. 2H). STAT5 phosphorylation and insulin-like growth factor 1 (IGF-1) are often used as biomarkers for the downstream signalling of the $\mathrm{GH}$ receptor in the liver. Fully restored IGF-1 gene expression and STAT5 phosphorylation in the liver of MC4RKO mice treated by dapagliflozin (Fig. 2I and J) confirmed the effect of restored pulsatile $\mathrm{GH}$ secretion. Muscle Igf1 expression in MC4RKO was also fully restored by dapagliflozin (Supplementary Fig. 2C), although plasma IGF-1 levels remain comparable among all groups (Supplementary Fig. 3C).

\section{Dapagliflozin prevents beta cell overgrowth and improves insulin sensitivity in MC4RKO mice}

To further address the plausible explanation for reduced hyperinsulinaemia, we assessed islet morphology and whole-body insulin sensitivity. MC4RKO mice had a 4-fold increase in beta cell mass and a 3-fold increase in the ratio of beta/alpha cell mass compared to that in WT mice. Dapagliflozin treatment reduced both parameters by approximately 60 and 40\%, respectively (Fig. 3A, B and D). Dapagliflozin treatment did not change alpha cell mass or plasma glucagon level (Fig. 3C and Supplementary Fig. 3B). Impaired Insulin sensitivity in MC4RKO mice was significantly improved following dapagliflozin treatment, as demonstrated by ITT (Fig. 3E and Supplementary Fig. 1E) and
HOMA-IR (Fig. 3F). At the cellular level, insulin-stimulated Akt phosphorylation in both white adipose tissue (WAT) and liver was significantly increased within 2 weeks of dapagliflozin treatment (Fig. 3G and H).

\section{Dapagliflozin promotes negative energy balance, reduces fat mass and increases lipid oxidation in MC4RKO mice}

To determine the phenotypic changes following the dapagliflozin treatment, body composition and indirect calorimeter were measured in these mice. With a deficit in satiety signalling (Huszar et al. 1997), MC4RKO mice had significantly increased food intake compared to WT mice, and this was not affected by the dapagliflozin treatment (Fig. 4A). Compare to WT mice, the body weight gain of MC4RKO mice was significantly greater and was attenuated by the dapagliflozin treatment (Fig. 4B and C). NMR measurement showed that MC4RKO mice had an approximately 4-fold increase in fat mass and a $30 \%$ increase in lean mass compared to WT mice (Fig. 4D and E). Dapagliflozin treatment reduced around 50\% of fat mass in MC4RKO mice without changing lean mass (Fig. 4D and E). The decreased weight of different adipose depots (Supplementary Fig. 1B) further confirmed the reduction of fat mass following dapagliflozin treatment. Since increased ectopic lipid accumulation is associated with insulin resistance (Boren et al. 2013), the triglyceride content was assessed in both liver and muscle. 
A
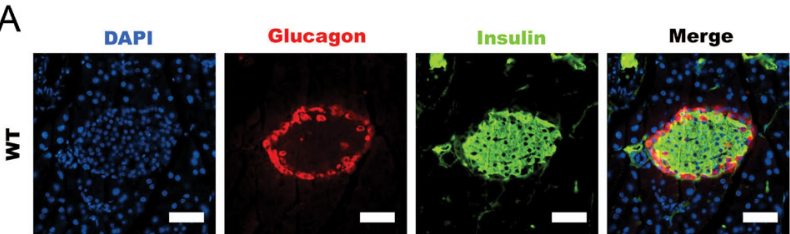

B
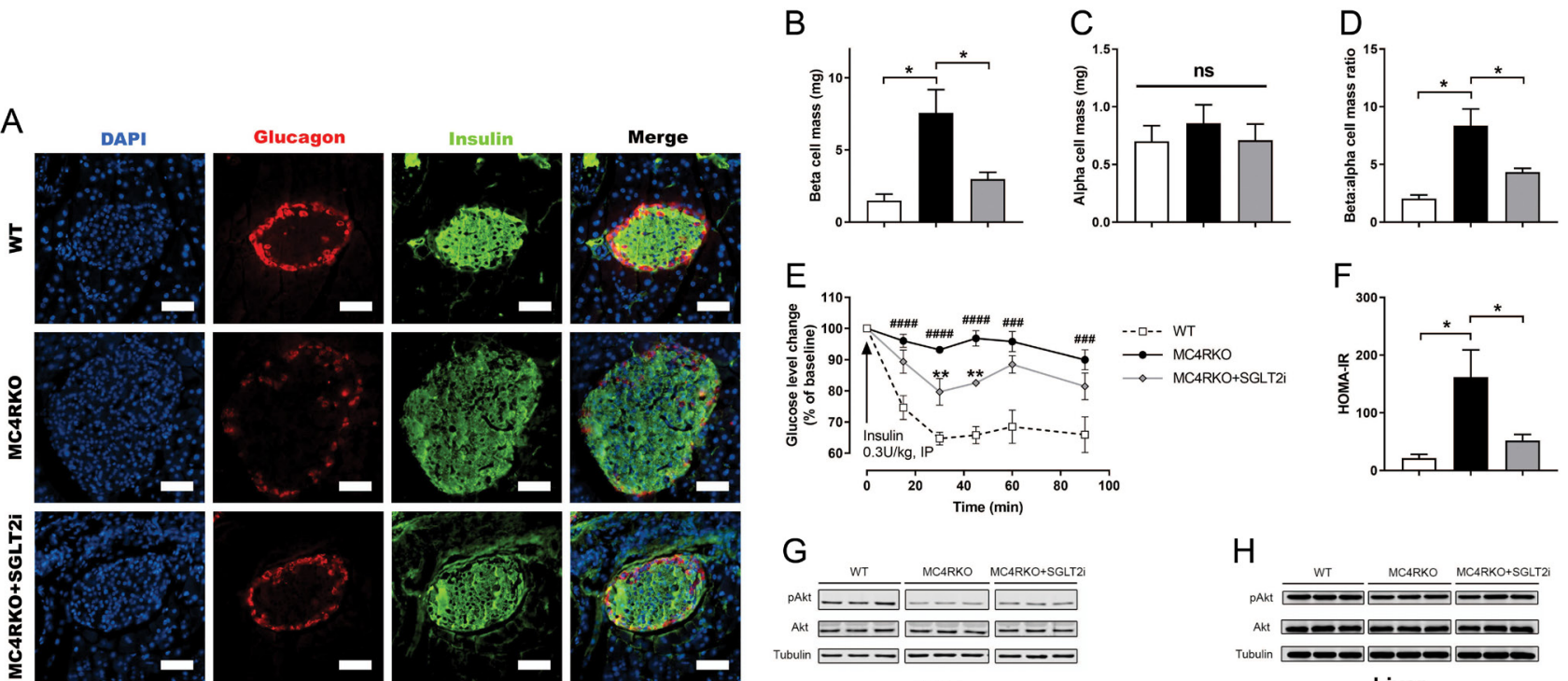

G
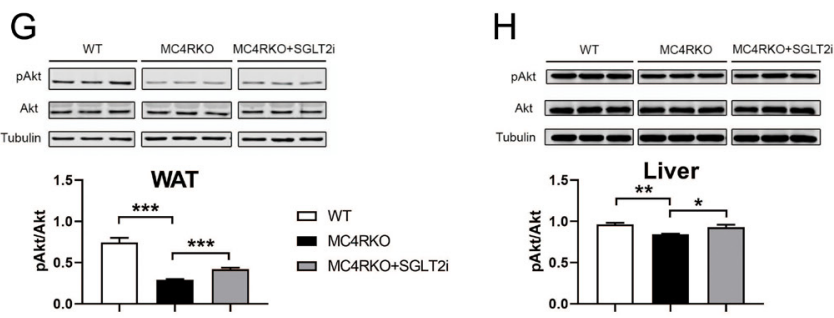

Figure 3

Dapagliflozin prevents beta cell overgrowth and improves insulin sensitivity in MC4RKO mice (A), representative images of pancreas sections, stained by glucagon and insulin antibody. Scale bars: $100 \mu \mathrm{m}$. (B, C and D) Quantitative analysis of beta cell mass (B), alpha cell mass (C) and the ratio of beta cell to alpha cell mass (D) were performed by Imaris Image Analysis Software. (E) Insulin tolerance test (ITT). (F) The homeostatic model assessment for insulin resistance (HOMA-IR). (G and H) Akt phosphorylation in WAT (G) and liver (H) following insulin injection in mice fasted for 6 h. Tubulin served as a loading control. Data were presented as means \pm S.E.M. For Immunohistochemistry, $n=3$ mice each group, and 20-40 islets per mouse were measured. For ITT, $n=6-8$ each group. $\# \# P<0.001, \# \# \# P<0.0001$ vs WT group; $* P<0.05, * * P<0.01$ vs MC4RKO group, ns, non-significance.

In MC4RKO mice, ectopic lipid accumulation increased in both liver and muscle, which was ameliorated by dapagliflozin treatment (Fig. 4F and G). Results from indirect calorimeter showed that MC4RKO mice had elevated respiratory exchange ratio (RER) in both light and dark phase, reflecting a dominant utilisation of carbohydrates over fats. The RER was reduced by dapagliflozin treatment (Fig. $4 \mathrm{H}$ and I). Together with an increase in plasma level of ketone body (Supplementary Fig. 3D), results suggested that dapagliflozin drove fuel utilisation towards fat. The decreased locomotor activity in MC4RKO mice was not changed by dapagliflozin treatment (Supplementary Fig. 1C and D). To determine whether changes in energy expenditure following dapagliflozin treatment in MC4RKO cohorts is a pure effect from the drug, we analysed the data with ANCOVA using lean mass as a covariate. There was a significant treatment effect $(F=19.379, P=0.002)$ without a significant covariate effect $(\mathrm{F}=0.187, P=0.677)$ nor interaction effect $(\mathrm{F}=0.096, P=0.766)$. These results indicated that reduced energy expenditure of MC4RKO mice in the dapagliflozin treatment group was largely due to the drug effect with little impact from lean mass change (Fig. 4J and K).

\section{Dapagliflozin increases expression of genes} involved in lipid oxidation, lipolysis, WAT browning, and decreases expression of genes involved in inflammation

Obesity is often accompanied by the disturbance of gene expression involved in lipid metabolism and inflammation. To determine the effect of dapagliflozin at the molecular level, we analysed relevant genes in liver (Fig. 5A), s.c. WAT (Fig. 5B) and visceral WAT (Fig. 5C). MC4RKO mice had decreased expression of genes involved in lipid oxidation in the liver (Ppara and Cpt1a) and lipolysis in WAT (Hsl), and dapagliflozin treatment corrected those alterations (Fig. 5A, B and C). The lipogenic gene expression levels were increased in the liver (Srebf1) and decreased in visceral WAT (Fasn and Ppary) of MC4RKO mice, and dapagliflozin treatment partially normalised those alterations (Fig. 5A and Supplementary Fig. 2A, B). Dapagliflozin treatment increased the expression level of WAT browning markers (Ppary, Pgc1 , Cidea, Eva1 and Tmem26) in MC4RKO mice although there was no change in Ucp1 expression level (Fig. 5B). The dissociation between the control of Ucp1 and that of $\operatorname{Pgc} 1 \alpha$ may be attributed to an impairment of 


\begin{tabular}{l|l|l|l|l|}
$\begin{array}{l}\text { Journal of } \\
\text { Endocrinology }\end{array}$ & Z Huang, L Huang et al. & $\begin{array}{l}\text { Dapagliflozin restores GH in } \\
\text { obese mice }\end{array}$ & $\mathbf{2 4 5 : 1}$ & $\mathbf{7}$ \\
\hline
\end{tabular}

A

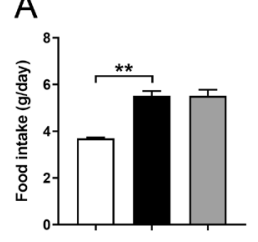

B

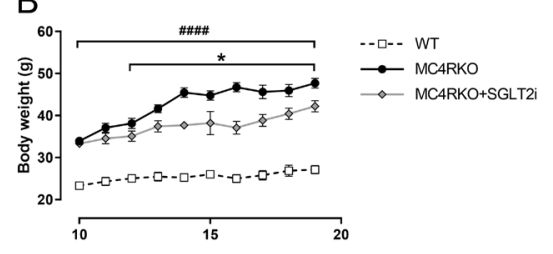

C

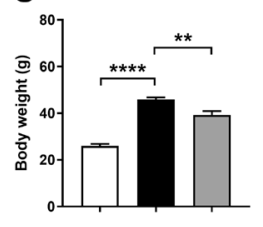

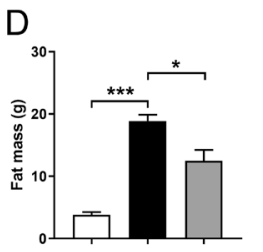

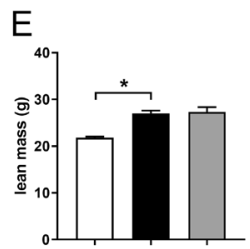

$\mathrm{H}$
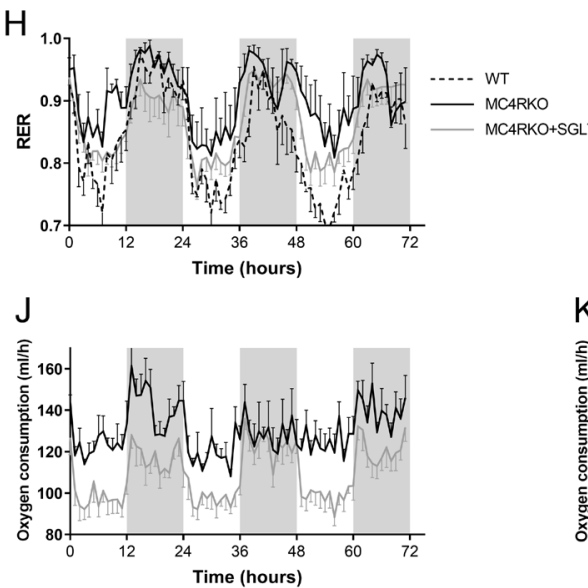
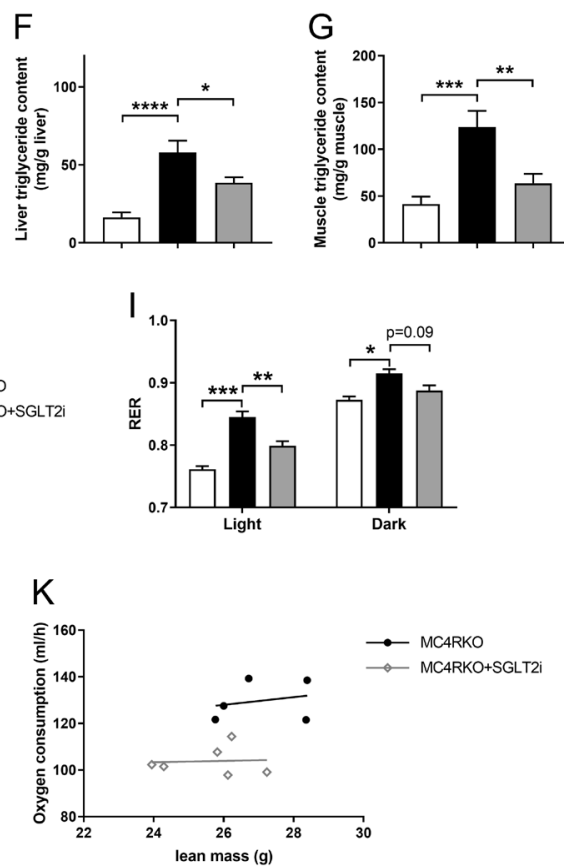

Figure 4

Dapagliflozin promotes negative energy balance, reduces fat mass and increases lipid oxidation in MC4RKO mice (A), daily food intake. (B) Body weight gain through the experiment. ( $C, D$ and $E$ ) At the terminal of the experiment, total body weight (C), fat mass (D) and lean mass (E) were measured. ( $\mathrm{F}$ and $\mathrm{G}$ ) Triglyceride content in liver (F) and muscle (G). ( $\mathrm{H}$ and J) Respiratory exchange ratio (RER) $(\mathrm{H})$ and oxygen consumption $(\mathrm{J})$ were measured during dark phase $(18: 00 \mathrm{~h}$ to $6: 00 \mathrm{~h}$ next day) marked by shaded area and light phase (6:00 $\mathrm{h}$ to $18: 00 \mathrm{~h}$ ) in half-hour intervals. (I) The average RER in both light and dark phase. (K) Scatter plots from ANCOVA showing raw oxygen consumption values plotted against lean body mass of MC4RKO and MC4RKO + SGLT2i mice. Data were presented as means \pm S.E.M., $n=6-8$ each group. \#\#\# $P<0.0001$ vs WT group; $* P<0.05$, $* * P<0.01, * * * P<0.001, * * * * P<0.0001$ vs MC4RKO group.

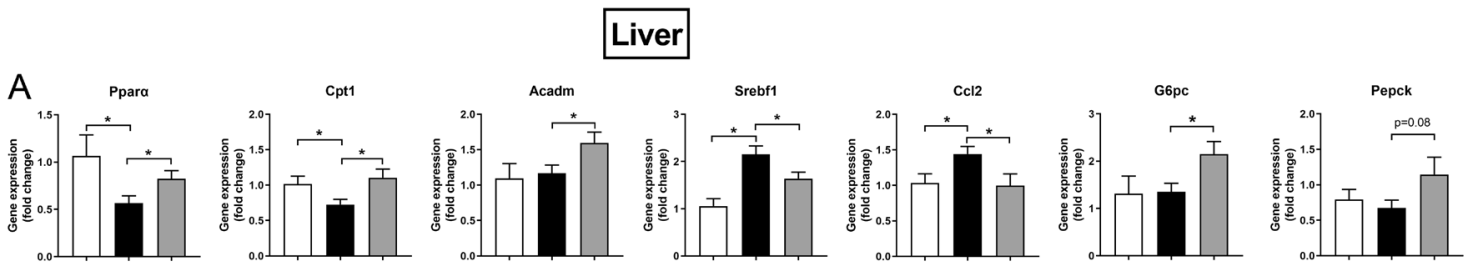

\section{Subcutaneous WAT}
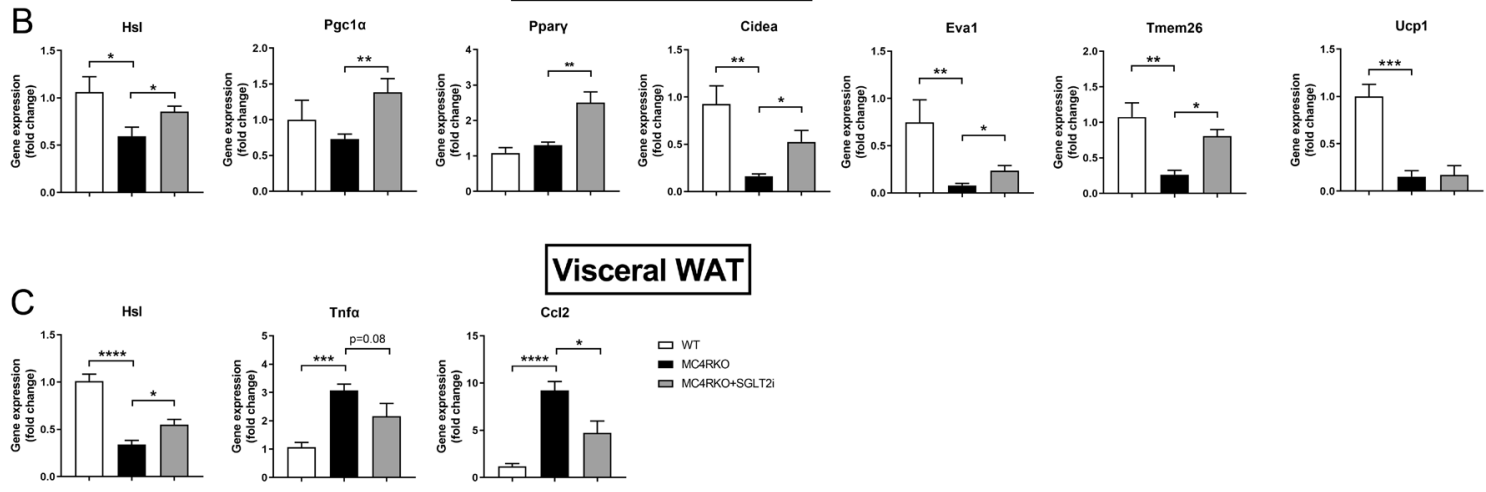

Visceral WAT

\section{므}

口 MCARKO+SGLT

Figure 5

Dapagliflozin increases expression of genes involved in lipid oxidation, lipolysis, WAT browning, and decreases expression of genes involved in inflammation. (A, B and C) Gene expression fold change was measured by qPCR, in liver (A), subcutaneous (B) and visceral (C) white adipose tissue (WAT). Data were presented as means \pm S.E.M., $n=6-8$ each group. ${ }^{\star} P<0.05, * \star P<0.01, * \star \star P<0.001, * \star \star \star P<0.0001$. 
$\beta$-adrenergic pathway in MC4R KO mice as melanocortin system modulates sympathetic outflow (Silva et al. 2014) and lack of $\beta$-adrenergic pathway dissociates the control of Ucp1 from that of $P g c 1 \alpha$ in cultured $\beta$-less mouse brown adipocytes (Lehr et al. 2006). In addition, the increased inflammation markers (Tnf $\alpha$ and Ccl2) in both liver and WAT in MC4RKO mice were reduced by dapagliflozin treatment (Fig. 5A and C) with a concurrent reduction of circulation inflammation marker resistin (Supplementary Fig. 3A).

\section{Discussion}

A precise balance between insulin and GH not only regulates glucose/lipid/protein metabolism in a homeostatic state but also plays an essential role in maintaining normal body composition. This study sought to define the metabolic effects of SGLT2i in hyperphagic obese mice and focus on the dominant endocrine elements: insulin and GH. Although there are a few studies investigating the effect of SGLT2i in obese animal models (Nakano et al. 2015, Benetti et al. 2016, Obata et al. 2016, Ji et al. 2017, Xu et al. 2017), none of them has reported the dynamic changes of $\mathrm{GH}$ following the treatment. Missing this key endocrine element may underestimate the pivotal effect of $\mathrm{GH}$ and its interaction with insulin on glucose/lipid/protein metabolism. In this study, we showed that dapagliflozin reduced hyperinsulinaemia and restored pulsatile GH secretion in obese MC4RKO mice. The substrate metabolism switched from carbohydrates to fats following the restoration of insulin and GH secretion. These changes led to decreased fat mass, improved insulin sensitivity and glucose tolerance, as well as preserved lean mass and delayed T2D progression. Changes of insulin, $\mathrm{GH}$ and substrate metabolism upon SGLT2i treatment in obese MC4RKO mice are reminiscent of fasting conditions in humans (Ho et al. 1988), indicating a physiological benefit (Patterson et al. 2015) from a pharmaceutical intervention in obesity.

The mechanisms of SGLT2 $i$ in regulating insulin secretion in T2D is mainly due to the removal of excess glucose in the blood and reducing the secretion pressure on beta cells (Kaneto et al. 2017). In our study, the slightly elevated random blood glucose level of MC4RKO mice was normalised following dapagliflozin treatment with a concomitant reduction in beta cell mass (Fig. 3). Decreased beta cell mass led to the reduction of hyperinsulinaemia, which improves whole-body insulin sensitivity (Shanik et al. 2008, Ning et al. 2011, Pedersen et al. 2015), and vice versa. Unlike previous studies on overt T2D animal models that show an increase in beta cell mass after SGLT2i treatment (Kimura et al. 2018), our results showed a decrease in beta cell mass in the treated mice. This contradictory results may be due to the different exposure durations of beta cells to glucotoxicity and lipotoxicity, with beta cells undergoing hyperplasia and hypertrophy (compensation) in obesity (Cerf 2013) whereas experiencing apoptosis (decompensation) in overt diabetes (Wajchenberg 2007).

Although it is well documented that dapagliflozin treatment raises plasma glucagon levels in most human and rodent study (Ferrannini et al. 2014, Merovci et al. 2014, Bonner et al. 2015, Timper et al. 2016, Millar et al. 2017, Saponaro et al. 2019), we did not observe changes in either circulating levels of glucagon or pancreatic glucagon positive cells following dapagliflozin treatment in MC4RKO mice. Such deviation may result from the loss of MC4R signalling as a recent study in MC4R-deficient mice demonstrates that MC4R is required for stimulation of glucagon release in response to hypoglycaemia or glucopaenia (Tooke et al. 2019). Interestingly, the expression levels of genes involved in gluconeogenesis (Fig. 5A) were upregulated following dapagliflozin treatment. Such changes may be less a matter of glucagon's effect but more likely to be a consequence of reduced hyperinsulinaemia or increased $\mathrm{GH}$.

In terms of changes in $\mathrm{GH}$, the mechanisms underlying reduced GH secretion in obesity are not fully understood but may involve perturbations in GH-releasing hormone (GHRH) and somatostatin tone, as well as increased feedback inhibition by FFA and insulin (Maccario et al. 2000). It is known that hyperinsulinaemia inhibits GH secretion from pituitary gland via insulin receptor both in vivo and in vitro, regardless of systemic insulin resistance (Luque \& Kineman 2006, Gahete et al. 2013). Therefore, restored pulsatile $\mathrm{GH}$ secretion after dapagliflozin treatment is likely to be a consequence of the reduced circulating insulin level. Detailed analysis of GH patterning further demonstrated that dapagliflozin treatment increased the amount of pulsatile $\mathrm{GH}$ secretion but did not change the pulse frequency (Fig. 2), indicating a restoration of the deficit in GH release without affecting the hypothalamic pulse generation by dapagliflozin. Although the direct effects of dapagliflozin on pituitary cells or GH regulatory neurons should also be considered, no Sglt2 mRNA expression was detected in mouse pituitary gland; neither in arcuate and periventricular nuclei of the hypothalamus, where GHRH/somatostatin neuron are located (Supplementary Fig. 2D and E). Thus, it is unlikely that SGLT2 has a direct effect on pituitary cells or hypothalamic 
GHRH/somatostatin neurons. The null effect of dapagliflozin on GHRH/somatostatin neurons is further supported by the unaltered GH secretion pattern following treatment.

The restoration of insulin and GH levels may play a vital role in the metabolic effects of SGLT2i in obesity. Hyperinsulinaemia causes increased lipid synthesis and inflammation in WAT, liver and muscle (Xu et al. 2003, Shanik et al. 2008, Pedersen et al. 2015, Samuel \& Shulman 2016, Morita et al. 2017). Amelioration of hyperinsulinaemia reduces lipid accumulation and improves insulin sensitivity by decreasing the expression level of genes regulating lipogenesis (Ning et al. 2011, D'Souza A et al. 2016) and inflammation (Mehran et al. 2012, Pedersen et al. 2015) in vivo. In consensus with previous studies of SGLT2i in obese animal models (Nakano et al. 2015, Benetti et al. 2016, Ji et al. 2017, Xu et al. 2017), SGLT2i in this report reduced lipid content and inflammation in WAT, liver and muscle (Fig. 4F and G). These changes led to improved insulin sensitivity as measured by ITT, HOMA-IR and insulin-stimulated Akt phosphorylation (Fig. 3). GH, on the other hand, induces lipolysis in WAT and lipid oxidation in the liver (Chia 2014). Low GH secretion (Luque et al. 2011) or GH receptor knockout (Cordoba-Chacon et al. 2018) leads to fat accumulation in mouse models. By contrast, GH injection in obese mouse results in a reduction of fat body mass (List et al. 2009). These pieces of evidence support a catabolic effect of GH on fat metabolism. It should be noted that exogenous GH injection may cause insulin resistance (Berryman et al. 2013) due to GH-induced increase in blood glucose and FFA flux. GH injection also causes desensitisation of GH receptor signalling pathways (Ji et al. 2002). Besides, exogenous GH injection does not mimic physiological pulsatile GH secretion pattern, which may exert distinct metabolic effects. In line with the previous study in mice (Obata et al. 2016), our study showed that dapagliflozin treatment increased lipolysis in WAT and lipid oxidation in the liver of MC4RKO mice. More importantly, dapagliflozin treatment restored physiological pulsatile GH secretion without changing long-term plasma FFA level (Supplementary Fig. 3E). Therefore, both insulin sensitivity and GH receptor signalling were improved by dapagliflozin treatment in obese MC4RKO mice. No change in circulating total IGF-1 was observed in the SGLT2i treatment group (Supplementary Fig. 3C), which is consistent with obese people in general (Nam et al. 1997, Lewitt et al. 2014). However, increased Igf1 mRNA expression was observed in muscle following the recovery of pulsatile $\mathrm{GH}$ (Supplementary Fig. 2C) and may exert protein preservation effects on lean mass through autocrine/paracrine manner (Philippou et al. 2007). It is worth to point out that discrete components of the GH secretory pattern may differentially affect IGF-I generation. For example, pulsatile $\mathrm{GH}$ is more effective than continuous $\mathrm{GH}$ infusion in increasing IGF-I mRNA levels in skeletal muscle in rodents (Isgaard et al. 1988). This may explain increased levels of $I g f 1$ mRNA expression in muscle in our study as we show an increase in pulsatile GH secretion following dapagliflozin treatment.

Studies show controversial results in energy metabolism changed by SGLT2i, especially in energy expenditure. A recent review suggests that the energy loss caused by SGLT2 inhibition may trigger compensatory hyperphagia in both human and rodents in most circumstances (Rajeev et al. 2016). Although MC4RKO mice with dapagliflozin treatment showed no change in food intake compared to the vehicle group, they had reduced body weight. This indicates an unparalleled change between body weight loss and the anticipated reduction in food intake. Therefore, compensatory hyperphagia may exist in dapagliflozin treated MC4RKO mice. Different to food intake, various changes in energy expenditure are found in previous animal studies, with increase (Naznin et al. 2017, Xu et al. 2017), decrease (Chiba et al. 2016, Kern et al. 2016) or no change (Devenny et al. 2012, Yokono et al. 2014) reported after SGLT2i treatments. The controversial results are possibly caused by differences in experimental designs as some studies used pair-fed animals (Devenny et al. 2012, Xu et al. 2017) while others used ad libitum feeding (Yokono et al. 2014, Chiba et al. 2016, Kern et al. 2016, Naznin et al. 2017). Alternatively, the method used to normalise and interpret the energy expenditure data may contribute to the different outcomes. According to a recent review (Kleinert et al. 2018), most approaches previously used to interpret energy expenditure are based on a direct comparison of uncorrected energy expenditure per individual or with correction by body weight. None of them takes body composition into account. This may cause misinterpretation of the data, given that energy expenditure is dependent on both lean (muscle) and fat (brown adipose tissue) body mass (Kleinert et al. 2018). Therefore, analysis of covariance (ANCOVA), which uses body weight and body composition as covariates, is more appropriate to analyse energy expenditure (Kleinert et al. 2018). To use ANCOVA, the data set should meet two assumptions: (1) independence of the covariate and treatment effect and (2) homogeneity of regression slopes (Miller \& Chapman 2001). By pre-analysing body weight, fat mass and lean mass as the covariate respectively, 
we confirmed that lean mass was independent of the treatment (assumption 1). We also confirmed that the slopes of linear trend lines for the two groups were similar (Fig. 4K) (assumption 2). By meeting with both criterion of ANCOVA, our analysis showed that dapagliflozin treatment reduced energy expenditure in MC4RKO mice. Since food intake was not changed by dapagliflozin in our study, reduced energy expenditure was more likely due to an alternative compensatory mechanism to combat negative energy balance caused by dapagliflozin. However, with a significant reduction of body weight in the long term, the net metabolic effect of dapagliflozin remained going towards negative energy balance.

In humans, the MC4R gene mutation is the most frequent single-gene cause of obesity, presenting in $6 \%$ of severe childhood obesity patients (Yeo et al. 1998, Farooqi et al. 2003). Dapagliflozin effectively restored insulin and GH secretions, as well as lipid/glucose metabolisms in obese MC4RKO mice, providing significant clinical relevance of such drug in treating obese patients with MC4R gene mutation. Whether SGLT2i has similar effects on general obese patients await further confirmation.

Although the outcomes of this study are promising, there remain a few limitations. For example, the detailed mechanisms by which dapagliflozin regulates GH secretion were not fully explored. Further studies on primary cultured somatotrophs or hypothalamus slices are encouraged. In addition, the current study focuses on the balance of insulin and GH without distinguishing the sole effect of insulin or GH on lipid/glucose metabolism. Although the STAT5 phosphorylation and local Igfl expression do provide strong evidence for the direct effects of $\mathrm{GH}$, further study using $\mathrm{GH}$ receptor blocker in MC4RKO mice or using transgenic mice with deficient $\mathrm{GH}$ receptor signalling may help to isolate the GH's role in glucose/lipid/protein metabolism following SGLT2i treatment.

In conclusion, this study provides evidence to support the promising effect of SGLT2i, dapagliflozin, in the restoration of pathological levels of insulin and $\mathrm{GH}$ in obese MC4RKO mice. This may lead to the beneficial effects in shifting substrate utilisation from glucose to lipid, reducing fat mass and improving insulin sensitivity. This study sheds lights on the potential application of SGLT2i in obese patients.

\section{Supplementary materials}

This is linked to the online version of the paper at https://doi.org/10.1530/ JOE-19-0385.

(C) 2020 Society for Endocrinology Published by Bioscientifica Ltd. Printed in Great Britain

\section{Declaration of interest}

The authors declare that there is no conflict of interest that could be perceived as prejudicing the impartiality of the research reported.

\section{Funding}

This work was supported by the National Health and Medical Research Council grant (APP1113494, 2016-2020) and The University of Queensland.

\section{Author contribution statement}

$\mathrm{Z} \mathrm{H}, \mathrm{L} \mathrm{H}$ and $\mathrm{C} C$ designed the experiments. Z H, L H, C W, S Z, X Q and $Y \mathrm{C}$ conducted the experiments and collected the data. $\mathrm{ZH}, \mathrm{L} \mathrm{H}$, J D V and Y Z performed data analysis. Z H, L H and C C wrote the manuscript. M C provided MC4RKO mice and valuable advice for the experiment design.

\section{Acknowledgements}

The authors thank AstraZeneca for providing dapagliflozin for this study. Zhengxiang Huang is a recipient of China Scholarship Council PhD scholarship and UQ International PhD scholarship.

\section{References}

Benetti E, Mastrocola R, Vitarelli G, Cutrin JC, Nigro D, Chiazza F, Mayoux E, Collino M \& Fantozzi R 2016 Empagliflozin protects against diet-induced NLRP-3 inflammasome activation and lipid accumulation. Journal of Pharmacology and Experimental Therapeutics 359 45-53. (https://doi.org/10.1124/jpet.116.235069)

Berryman DE, Glad CA, List EO \& Johannsson G 2013 The GH/IGF-1 axis in obesity: pathophysiology and therapeutic considerations. Nature Reviews: Endocrinology 9 346-356. (https://doi.org/10.1038/nrendo.2013.64)

Bonner C, Kerr-Conte J, Gmyr V, Queniat G, Moerman E, Thévenet J, Beaucamps C, Delalleau N, Popescu I \& Malaisse WJ 2015 Inhibition of the glucose transporter SGLT2 with dapagliflozin in pancreatic alpha cells triggers glucagon secretion. Nature Medicine 21512. (https://doi.org/10.1038/nm.3828)

Boren J, Taskinen MR, Olofsson SO \& Levin M 2013 Ectopic lipid storage and insulin resistance: a harmful relationship. Journal of Internal Medicine 274 25-40. (https://doi.org/10.1111/joim.12071)

Cerf ME 2013 Beta cell dysfunction and insulin resistance. Frontiers in Endocrinology 4 37. (https://doi.org/10.3389/fendo.2013.00037)

Chia DJ 2014 Minireview: mechanisms of growth hormone-mediated gene regulation. Molecular Endocrinology 28 1012-1025. (https://doi. org/10.1210/me.2014-1099)

Chiba Y, Yamada T, Tsukita S, Takahashi K, Munakata Y, Shirai Y, Kodama S, Asai Y, Sugisawa T, Uno K, et al. 2016 Dapagliflozin, a sodium-glucose co-transporter 2 inhibitor, acutely reduces energy expenditure in BAT via neural signals in mice. PLOS ONE 11 e0150756. (https://doi.org/10.1371/journal.pone.0150756)

Cordoba-Chacon J, Sarmento-Cabral A, Del Rio-Moreno M, Diaz-Ruiz A, Subbaiah PV \& Kineman RD 2018 Adult-onset hepatocyte GH resistance promotes NASH in male mice, Without severe systemic metabolic dysfunction. Endocrinology 159 3761-3774. (https://doi. org/10.1210/en.2018-00669)

D'Souza AM, Johnson JD, Clee SM \& Kieffer TJ 2016 Suppressing hyperinsulinemia prevents obesity but causes rapid onset of diabetes in leptin-deficient Lepob/ob mice. Molecular Metabolism 5 1103-1112. (https://doi.org/10.1016/j.molmet.2016.09.007)

da Silva AA, Do Carmo JM, Wang Z \& Hall JE 2014 The brain melanocortin system, sympathetic control, and obesity hypertension. Physiology 29 196-202. (https://doi.org/10.1152/physiol.00061.2013)

Devenny JJ, Godonis HE, Harvey SJ, Rooney S, Cullen MJ \& Pelleymounter MA 2012 Weight loss induced by chronic dapagliflozin 
treatment is attenuated by compensatory hyperphagia in dietinduced obese (DIO) rats. Obesity 20 1645-1652. (https://doi. org/10.1038/oby.2012.59)

Farooqi IS, Keogh JM, Yeo GS, Lank EJ, Cheetham T \& O'Rahilly S 2003 Clinical spectrum of obesity and mutations in the melanocortin 4 receptor gene. New England Journal of Medicine 348 1085-1095. (https://doi.org/10.1056/NEJMoa022050)

Ferrannini E, Muscelli E, Frascerra S, Baldi S, Mari A, Heise T, Broedl UC \& Woerle HJ 2014 Metabolic response to sodium-glucose cotransporter 2 inhibition in type 2 diabetic patients. Journal of Clinical Investigation 124 499-508. (https://doi.org/10.1172/JCI72227)

Gahete MD, Córdoba-Chacón J, Lin Q, Brüning JC, Kahn CR, Castaño JP, Christian H, Luque RM \& Kineman RD 2013 Insulin and IGF-I inhibit GH synthesis and release in vitro and in vivo by separate mechanisms. Endocrinology 154 2410-2420. (https://doi.org/10.1210/ en.2013-1261)

Ho KY, Veldhuis JD, Johnson ML, Furlanetto R, Evans WS, Alberti KG \& Thorner MO 1988 Fasting enhances growth hormone secretion and amplifies the complex rhythms of growth hormone secretion in man. Journal of Clinical Investigation 81 968-975. (https://doi.org/10.1172/ JCI113450)

Huang L, Steyn FJ, Tan HY, Xie TY, Veldhuis JD, Ngo ST \& Chen C 2012 The decline in pulsatile GH secretion throughout early adulthood in mice is exacerbated by dietary-induced weight gain. Endocrinology 153 4380-4388. (https://doi.org/10.1210/en.2012-1178)

Huszar D, Lynch CA, Fairchild-Huntress V, Dunmore JH, Fang Q, Berkemeier LR, Gu W, Kesterson RA, Boston BA, Cone RD, et al. 1997 Targeted disruption of the melanocortin-4 receptor results in obesity in mice. Cell 88 131-141. (https://doi.org/10.1016/s00928674(00)81865-6)

Isgaard J, Carlsson L, Isaksson OG \& Jansson JO 1988 Pulsatile intravenous growth hormone $(\mathrm{GH})$ infusion to hypophysectomized rats increases insulin-like growth factor I messenger ribonucleic acid in skeletal tissues more effectively than continuous GH infusion. Endocrinology 123 2605-2610. (https://doi.org/10.1210/endo-123-6-2605)

Ji S, Frank SJ \& Messina JL 2002 Growth hormone-induced differential desensitization of STAT5, ERK, and Akt phosphorylation. Journal of Biological Chemistry 277 28384-28393. (https://doi.org/10.1074/jbc. m111723200)

Ji W, Zhao M, Wang M, Yan W, Liu Y, Ren S, Lu J, Wang B \& Chen L 2017 Effects of canagliflozin on weight loss in high-fat diet-induced obese mice. PLoS ONE 12 e0179960. (https://doi.org/10.1371/journal. pone.0179960)

Kaneto H, Obata A, Kimura T, Shimoda M, Okauchi S, Shimo N, Matsuoka TA \& Kaku K 2017 Beneficial effects of sodium-glucose cotransporter 2 inhibitors for preservation of pancreatic beta-cell function and reduction of insulin resistance. Journal of Diabetes 9 219-225. (https://doi.org/10.1111/1753-0407.12494)

Kern M, Kloting N, Mark M, Mayoux E, Klein T \& Bluher M 2016 The SGLT2 inhibitor empagliflozin improves insulin sensitivity in $\mathrm{db} /$ $\mathrm{db}$ mice both as monotherapy and in combination with linagliptin. Metabolism: Clinical and Experimental 65 114-123. (https://doi. org/10.1016/j.metabol.2015.10.010)

Kimura T, Obata A, Shimoda M, Okauchi S, Kanda-Kimura Y, Nogami Y, Moriuchi S, Hirukawa H, Kohara K, Nakanishi S, et al. 2018 Protective effects of the SGLT2 inhibitor luseogliflozin on pancreatic $\beta$-cells in $\mathrm{db} / \mathrm{db}$ mice: the earlier and longer, the better. Diabetes, Obesity and Metabolism 20 2442-2457. (https://doi.org/10.1111/dom.13400)

Kleinert M, Clemmensen C, Hofmann SM, Moore MC, Renner S, Woods SC, Huypens P, Beckers J, De Angelis MH, Schürmann A, et al. 2018 Animal models of obesity and diabetes mellitus. Nature Reviews: Endocrinology 14 140-162. (https://doi.org/10.1038/nrendo.2017.161)

Lehr L, Canola K, Asensio C, Jimenez M, Kuehne F, Giacobino JP \& Muzzin P 2006 The control of UCP1 is dissociated from that of PGC- $1 \alpha$ or of mitochondriogenesis as revealed by a study using $\beta$-less mouse brown adipocytes in culture. FEBS Letters $\mathbf{5 8 0} 4661-4666$. (https://doi.org/10.1016/j.febslet.2006.07.037)
Lewitt MS, Dent MS \& Hall K 2014 The insulin-like growth factor system in obesity, insulin resistance and type 2 diabetes mellitus. Journal of Clinical Medicine 3 1561-1574. (https://doi.org/10.3390/jcm3041561)

List EO, Palmer AJ, Berryman DE, Bower B, Kelder B \& Kopchick JJ 2009 Growth hormone improves body composition, fasting blood glucose, glucose tolerance and liver triacylglycerol in a mouse model of dietinduced obesity and type 2 diabetes. Diabetologia 52 1647-1655. (https://doi.org/10.1007/s00125-009-1402-z)

Luque RM \& Kineman RD 2006 Impact of obesity on the growth hormone axis: evidence for a direct inhibitory effect of hyperinsulinemia on pituitary function. Endocrinology $\mathbf{1 4 7}$ 2754-2763. (https://doi.org/10.1210/en.2005-1549)

Luque RM, Lin Q, Cordoba-Chacon J, Subbaiah PV, Buch T, Waisman A, Vankelecom H \& Kineman RD 2011 Metabolic impact of adult-onset, isolated, growth hormone deficiency (AOiGHD) due to destruction of pituitary somatotropes. PLOS ONE 6 e15767. (https://doi.org/10.1371/ journal.pone.0015767)

Maccario M, Grottoli S, Procopio M, Oleandri SE, Rossetto R, Gauna C, Arvat E \& Ghigo E 2000 The GH/IGF-I axis in obesity: influence of neuroendocrine and metabolic factors. International Journal of Obesity and Related Metabolic Disorders 24 (Supplement 2) S96-S99. (https:// doi.org/10.1038/sj.ijo.0801289)

Mehran AE, Templeman NM, Brigidi GS, Lim GE, Chu KY, Hu X, Botezelli JD, Asadi A, Hoffman BG, Kieffer TJ, et al. 2012 Hyperinsulinemia drives diet-induced obesity independently of brain insulin production. Cell Metabolism 16 723-737. (https://doi. org/10.1016/j.cmet.2012.10.019)

Merovci A, Solis-Herrera C, Daniele G, Eldor R, Fiorentino TV, Tripathy D, Xiong J, Perez Z, Norton L, Abdul-Ghani MA, et al. 2014 Dapagliflozin improves muscle insulin sensitivity but enhances endogenous glucose production. Journal of Clinical Investigation 124 509-514. (https://doi. org/10.1172/JCI70704)

Merovci A, Abdul-Ghani M, Mari A, Solis-Herrera C, Xiong J, Daniele G, Tripathy D \& Defronzo RA 2016 Effect of dapagliflozin with and without acipimox on insulin sensitivity and insulin secretion in T2DM males. Journal of Clinical Endocrinology and Metabolism 101 1249-1256. (https://doi.org/10.1210/jc.2015-2597)

Miller GA \& Chapman JP 2001 Misunderstanding analysis of covariance. Journal of Abnormal Psychology 110 40-48. (https://doi. org/10.1037//0021-843x.110.1.40)

Millar P, Pathak N, Parthsarathy V, Bjourson AJ, O'kane M, Pathak V, Moffett RC, Flatt PR \& Gault VA 2017 Metabolic and neuroprotective effects of dapagliflozin and liraglutide in diabetic mice. Journal of Endocrinology 234 255-267. (https://doi.org/10.1530/JOE-17-0263)

Morino K, Inoue H, Fuse K, Tanaka S, Kondo K, Arima H, Miura K, Sato D, Ohashi N, Ida S, et al. 2018 Ipragliflozin, a SGLT2 inhibitor, reduced body weight and fat mass but not muscle mass in Japanese type 2 diabetic patients treated with insulin - a randomized clinical trial. Diabetes 67 1199-P. (https://doi.org/10.2337/db18-1199-P)

Morita I, Tanimoto K, Akiyama N, Naya N, Fujieda K, Iwasaki T \& Yukioka H 2017 Chronic hyperinsulinemia contributes to insulin resistance under dietary restriction in association with altered lipid metabolism in Zucker diabetic fatty rats. American Journal of Physiology: Endocrinology and Metabolism 312 E264-E272. (https://doi. org/10.1152/ajpendo.00342.2016)

Mosa R, Huang L, Li H, Grist M, Leroith D \& Chen C 2017a Long-term treatment with the ghrelin receptor antagonist, [D-Lys3]-GHRP-6 does not improve glucose homeostasis in non-obese diabetic MKR mice. American Journal of Physiology: Regulatory, Integrative and Comparative Physiology 314 R71-R83. (https://doi.org/10.1152/ajpregu.00157.2017)

Mosa R, Huang L, Wu Y, Fung C, Mallawakankanamalage O, Leroith D \& Chen C $2017 b$ Hexarelin, a growth hormone secretagogue, improves lipid metabolic aberrations in nonobese insulin-resistant male MKR mice. Endocrinology 158 3174-3187. (https://doi.org/10.1210/en.201700168)

Nakano S, Katsuno K, Isaji M, Nagasawa T, Buehrer B, Walker S, Wilkison WO \& Cheatham B 2015 Remogliflozin etabonate improves 
fatty liver disease in diet-induced obese male mice. Journal of Clinical and Experimental Hepatology 5 190-198. (https://doi.org/10.1016/j. jceh.2015.02.005)

Nam SY, Lee EJ, Kim KR, Cha BS, Song YD, Lim SK, Lee HC \& Huh KB 1997 Effect of obesity on total and free insulin-like growth factor (IGF)-1, and their relationship to IGF-binding protein (BP)-1, IGFBP-2, IGFBP-3, insulin, and growth hormone. International Journal of Obesity and Related Metabolic Disorders 21 355-359. (https://doi.org/10.1038/ sj.ijo.0800412)

Naznin F, Sakoda H, Okada T, Tsubouchi H, Waise TM, Arakawa K \& Nakazato M 2017 Canagliflozin, a sodium glucose cotransporter 2 inhibitor, attenuates obesity-induced inflammation in the nodose ganglion, hypothalamus, and skeletal muscle of mice. European Journal of Pharmacology 794 37-44. (https://doi.org/10.1016/j. ejphar.2016.11.028)

Ning J, Hong T, Yang X, Mei S, Liu Z, Liu HY \& Cao W 2011 Insulin and insulin signaling play a critical role in fat induction of insulin resistance in mouse. American Journal of Physiology: Endocrinology and Metabolism 301 E391-E401. (https://doi.org/10.1152/ajpendo.00164.2011)

Obata A, Kubota N, Kubota T, Iwamoto M, Sato H, Sakurai Y, Takamoto I, Katsuyama H, Suzuki Y, Fukazawa M, et al. 2016 Tofogliflozin improves insulin resistance in skeletal muscle and accelerates lipolysis in adipose tissue in male mice. Endocrinology 157 1029-1042. (https:// doi.org/10.1210/en.2015-1588)

Patterson RE, Laughlin GA, Lacroix AZ, Hartman SJ, Natarajan L, Senger CM, Martínez ME, Villaseñor A, Sears DD, Marinac CR, et al. 2015. Intermittent fasting and human metabolic health. Journal of the Academy of Nutrition and Dietetics 115 1203-1212. (https://doi. org/10.1016/j.jand.2015.02.018)

Pedersen DJ, Guilherme A, Danai LV, Heyda L, Matevossian A, Cohen J, Nicoloro SM, Straubhaar J, Noh HL, Jung D, et al. 2015 A major role of insulin in promoting obesity-associated adipose tissue inflammation. Molecular Metabolism 4 507-518. (https://doi.org/10.1016/j. molmet.2015.04.003)

Philippou A, Maridaki M, Halapas A \& Koutsilieris M 2007 The role of the insulin-like growth factor 1 (IGF-1) in skeletal muscle physiology. In Vivo 21 45-54.

Rajeev SP, Cuthbertson DJ \& Wilding JP 2016 Energy balance and metabolic changes with sodium-glucose co-transporter 2 inhibition. Diabetes, Obesity and Metabolism 18 125-134. (https://doi. org/10.1111/dom.12578)

Samuel VT \& Shulman GI 2016 The pathogenesis of insulin resistance: integrating signaling pathways and substrate flux. Journal of Clinical Investigation 126 12-22. (https://doi.org/10.1172/JCI77812)

Saponaro C, Gmyr V, Thévenet J, Moerman E, Delalleau N, Pasquetti G, Coddeville A, Quenon A, Daoudi M, Hubert T, et al. 2019. The GLP1R agonist liraglutide reduces hyperglucagonemia induced by the SGLT2 inhibitor dapagliflozin via somatostatin release. Cell Reports 281447. e4-1454.e4. (https://doi.org/10.1016/j.celrep.2019.07.009)

Shanik MH, Xu Y, Skrha J, Dankner R, Zick Y \& Roth J 2008 Insulin resistance and hyperinsulinemia: is hyperinsulinemia the cart or the horse? Diabetes Care 31 (Supplement 2) S262-S268. (https://doi org/10.2337/dc08-s264)

Speakman JR, Fletcher Q \& Vaanholt L 2013 The '39 steps': an algorithm for performing statistical analysis of data on energy intake and expenditure. Disease Models and Mechanisms 6 293-301. (https://doi. org/10.1242/dmm.009860)

Steyn FJ, Huang L, Ngo ST, Leong JW, Tan HY, Xie TY, Parlow AF, Veldhuis JD, Waters MJ \& Chen C 2011 Development of a method for the determination of pulsatile growth hormone secretion in mice. Endocrinology 152 3165-3171. (https://doi.org/10.1210/en.2011-0253)
Steyn FJ, Leong JW, Huang L, Tan HY, Xie TY, Nelson C, Waters MJ, Veldhuis JD, Epelbaum J \& Chen C 2012 GH does not modulate the early fasting-induced release of free fatty acids in mice. Endocrinology 153 273-282. (https://doi.org/10.1210/en.2011-1681)

Surya S, Horowitz JF, Goldenberg N, Sakharova A, Harber M, Cornford AS, Symons K \& Barkan AL 2009 The pattern of growth hormone delivery to peripheral tissues determines insulin-like growth factor- 1 and lipolytic responses in obese subjects. Journal of Clinical Endocrinology and Metabolism 94 2828-2834. (https://doi.org/10.1210/jc.2009-0638)

Tan HY, Steyn FJ, Huang L, Cowley M, Veldhuis JD \& Chen C 2016 Hyperphagia in male melanocortin 4 receptor deficient mice promotes growth independently of growth hormone. Journal of Physiology 594 7309-7326. (https://doi.org/10.1113/JP272770)

Tannenbaum GS, Martin JB \& Colle E 1976 Ultradian growth hormone rhythm in the rat: effects of feeding, hyperglycemia, and insulininduced hypoglycemia. Endocrinology 99 720-727. (https://doi. org/10.1210/endo-99-3-720)

Templeman NM, Skovso S, Page MM, Lim GE \& Johnson JD 2017 A causal role for hyperinsulinemia in obesity. Journal of Endocrinology 232 R173-R183. (https://doi.org/10.1530/JOE-16-0449)

Timper K, Dalmas E, Dror E, Rütti S, Thienel C, Sauter NS, Bouzakri K, Bédat B, Pattou F, Kerr-Conte J, et al. 2016 Glucose-dependent insulinotropic peptide stimulates glucagon-like peptide 1 production by pancreatic islets via interleukin 6, produced by $\alpha$ cells. Gastroenterology 151 165-179. (https://doi.org/10.1053/j.gastro.2016.03.003)

Tooke BP, Yu H, Adams JM, Jones GL, Sutton-Kennedy T, Mundada L, Qi NR, Low MJ \& Chhabra KH 2019 Hypothalamic POMC or MC4R deficiency impairs counterregulatory responses to hypoglycemia in mice. Molecular Metabolism 20 194-204. (https://doi.org/10.1016/j.molmet.2018.11.004)

Veldhuis JD, Iranmanesh A, Ho KK, Waters MJ, Johnson ML \& Lizarralde G 1991 Dual defects in pulsatile growth hormone secretion and clearance subserve the hyposomatotropism of obesity in man. Journal of Clinical Endocrinology and Metabolism 72 51-59. (https://doi. org/10.1210/jcem-72-1-51)

Wajchenberg BL $2007 \beta$-cell failure in diabetes and preservation by clinical treatment. Endocrine Reviews 28 187-218. (https://doi. org/10.1210/10.1210/er.2006-0038)

Winer LM, Shaw MA \& Baumann G 1990 Basal plasma growth hormone levels in man: new evidence for rhythmicity of growth hormone secretion. Journal of Clinical Endocrinology and Metabolism 70 1678-1686. (https://doi.org/10.1210/jcem-70-6-1678)

Xu H, Barnes GT, Yang Q, Tan G, Yang D, Chou CJ, Sole J, Nichols A, Ross JS, Tartaglia LA, et al. 2003 Chronic inflammation in fat plays a crucial role in the development of obesity-related insulin resistance. Journal of Clinical Investigation 112 1821-1830. (https://doi. org/10.1172/JCI19451)

Xu L, Nagata N, Nagashimada M, Zhuge F, Ni Y, Chen G, Mayoux E, Kaneko S \& Ota T 2017 SGLT2 inhibition by empagliflozin promotes fat utilization and browning and attenuates inflammation and insulin resistance by polarizing M2 macrophages in diet-induced obese mice. EBioMedicine 20 137-149. (https://doi.org/10.1016/j. ebiom.2017.05.028)

Yeo GS, Farooqi IS, Aminian S, Halsall DJ, Stanhope RG \& O'rahilly S 1998 A frameshift mutation in MC4R associated with dominantly inherited human obesity. Nature Genetics 20 111-112. (https://doi. org/10.1038/2404)

Yokono M, Takasu T, Hayashizaki Y, Mitsuoka K, Kihara R, Muramatsu Y, Miyoshi S, Tahara A, Kurosaki E, Li Q, et al. 2014 SGLT2 selective inhibitor ipragliflozin reduces body fat mass by increasing fatty acid oxidation in high-fat diet-induced obese rats. European Journal of Pharmacology 727 66-74. (https://doi.org/10.1016/j.ejphar.2014.01.040)

Received in final form 17 December 2019

Accepted 21 January 2020

Accepted Manuscript published online 24 January 2020 https://joe.bioscientifica.com https://doi.org/10.1530/JOE-19-0385 (c) 2020 Society for Endocrinology Published by Bioscientifica Ltd. Printed in Great Britain 